University of Wollongong

Research Online

Faculty of Engineering and Information

Faculty of Engineering and Information

Sciences - Papers: Part A

Sciences

$1-1-2016$

Improved performance of ballasted rail track using geosynthetics and rubber shockmat

Sanjay Nimbalkar

University of Wollongong, sanjayn@uow.edu.au

Buddhima Indraratna

University of Wollongong, indra@uow.edu.au

Follow this and additional works at: https://ro.uow.edu.au/eispapers

Part of the Engineering Commons, and the Science and Technology Studies Commons

Research Online is the open access institutional repository for the University of Wollongong. For further information contact the UOW Library: research-pubs@uow.edu.au 


\title{
Improved performance of ballasted rail track using geosynthetics and rubber shockmat
}

\begin{abstract}
Large repetitive wheel loads from heavy haul and passenger trains can cause significant track deformation that leads to poor track geometry and safety issues. The inclusion of geosynthetics and rubber mats (i.e., shockmat) in critical sections in the track for reducing these adverse effects was further examined through an extensive field trial in the town of Singleton, New South Wales (NSW), Australia. Four types of geosynthetics and a shockmat were installed below the ballast layer in selected sections of track constructed on three different subgrades (soft alluvial clay, hard rock, and concrete bridge), and the performance of the instrumented track was monitored for five years under in-service conditions including tamping operations. The measured stress-deformation response indicates that the geosynthetics effectively control the long-term and transient strains in the ballast layer, with the obvious benefit of reducing maintenance costs. The study also showed that the aperture size of geogrids in the range of 1.1 times the mean particle size of the ballast was most effective. The placement of shockmat on a concrete bridge contributed to reduced ballast breakage. The dynamic amplification of stresses induced by moving trains was observed, and it became more pronounced at higher axle loads and train speeds. The dynamic track modulus was evaluated adopting the concept of modified beam on an elastic foundation (BOEF), and this approach was found to be largely influenced by the axle load, train speed, placement of synthetic inclusions, and type of subgrade.
\end{abstract}

\section{Keywords}

shockmat, ballasted, rail, improved, track, performance, geosynthetics, rubber

\section{Disciplines \\ Engineering | Science and Technology Studies}

\section{Publication Details}

Nimbalkar, S. \& Indraratna, B. (2016). Improved performance of ballasted rail track using geosynthetics and rubber shockmat. Journal of Geotechnical and Geoenvironmental Engineering, 142 (8),

04016031-1-04016031-13. 


\title{
Improved Performance of Ballasted Rail Track Using Geosynthetics and Rubber Shockmat
}

\author{
Sanjay Nimbalkar, Ph.D. ${ }^{1}$; and Buddhima Indraratna, Ph.D., F.ASCE ${ }^{2}$
}

\begin{abstract}
Large repetitive wheel loads from heavy haul and passenger trains can cause significant track deformation that leads to poor track geometry and safety issues. The inclusion of geosynthetics and rubber mats (i.e., shockmat) in critical sections in the track for reducing these adverse effects was further examined through an extensive field trial in the town of Singleton, New South Wales (NSW), Australia. Four types of geosynthetics and a shockmat were installed below the ballast layer in selected sections of track constructed on three different subgrades (soft alluvial clay, hard rock, and concrete bridge), and the performance of the instrumented track was monitored for five years under in-service conditions including tamping operations. The measured stress-deformation response indicates that the geosynthetics effectively control the long-term and transient strains in the ballast layer, with the obvious benefit of reducing maintenance costs. The study also showed that the aperture size of geogrids in the range of 1.1 times the mean particle size of the ballast was most effective. The placement of shockmat on a concrete bridge contributed to reduced ballast breakage. The dynamic amplification of stresses induced by moving trains was observed, and it became more pronounced at higher axle loads and train speeds. The dynamic track modulus was evaluated adopting the concept of modified beam on an elastic foundation (BOEF), and this approach was found to be largely influenced by the axle load, train speed, placement of synthetic inclusions, and type of subgrade. DOI: 10.1061/(ASCE)GT.1943-5606.0001491. () 2016 American Society of Civil Engineers.
\end{abstract}

Author keywords: Railroad tracks; Repeated loads; Railroad ballast; Deformation; Degradation; Geosynthetics.

\section{Introduction}

Railways form one of the largest worldwide networks catering to passenger and freight transportation. In recent years the increased demand of such transportation has led to the use of heavier and faster trains, resulting in large traffic-induced stresses in rail tracks. This often causes significant cumulative deformation as well as the loss of stability and geometry of conventional tracks. Such degradation under repetitive wheel loads results mainly from a loss of stability in the ballast layer through particle breakage, fouling, cyclic densification and associated deformations, as well as settlement of the underlying layers of subballast and subgrade (Neidhart 2001; Suiker et al. 2005; Aursudkij et al. 2009; Kennedy et al. 2012; Sun et al. 2014; Indraratna et al. 2013, 2015). Further degradation can also occur from impact loads induced from wheel-rail irregularities as well as abrupt changes in track stiffness (Jenkins et al. 1974). The loss of stability and geometry has inevitably led to substantial increases in the cost of track maintenance, which mainly involves tamping the ballast. The performance of the ballast is also influenced by the type of subgrade (Sussmann et al. 2001); hence, subgrade stabilization is

${ }^{1}$ Research Fellow, Centre for Geomechanics and Railway Engineering; ARC Centre of Excellence for Geotechnical Science and Engineering, Univ. of Wollongong, Wollongong, NSW 2522, Australia. E-mail: sanjayn@uow.edu.au

${ }^{2}$ Professor of Civil Engineering and Research Director, Centre for Geomechanics and Railway Engineering, Univ. of Wollongong, Wollongong, NSW 2522, Australia (corresponding author). E-mail: indra@uow.edu.au

Note. This manuscript was submitted on June 24, 2015; approved on December 31, 2015; published online on April 4, 2016. Discussion period open until September 4, 2016; separate discussions must be submitted for individual papers. This paper is part of the Journal of Geotechnical and Geoenvironmental Engineering, (C) ASCE, ISSN 1090-0241. sometimes required for enhanced track performance and increased longevity.

Laboratory studies have shown that the inclusion of geosynthetics is a viable way of reducing the adverse effects of repetitive wheel loads and improving the overall track performance (Göbel et al. 1994; Raymond 2002; Indraratna et al. 2007; Indraratna and Nimbalkar 2013). A stiff track substructure, such as a concrete bridge deck, can create severe dynamic loading under operating conditions, and installing rubber mats (sometimes referred to as shockmats) can attenuate these loads. The use of shockmat to reduce dynamic stresses and vibrations is evident from a few recent studies (Costa et al. 2012; Ferreira and López-Pita 2013); however, their effects on ballast breakage and deformations are not yet fully understood or analyzed in a quantifiable manner. Preliminary laboratory tests conducted using large-scale drop-weight impact equipment have revealed that rubber shockmats could decrease impact-induced strains in the ballast layer by as much as $50 \%$ (Nimbalkar et al. 2012). Only a very limited number of full-scale studies have been carried out to investigate the effects of geosynthetic reinforcement and shockmats on in situ track performance (Fernandes et al. 2008; Indraratna et al. 2010, 2014a). However, effects of tamping and varied subgrade conditions on long-term track performance, including subsequent improvements through the use of artificial inclusions, have not been investigated in a systematic manner.

The influence of axle load and train speed on the dynamic stress and track modulus also requires more in-depth study. As such, some sections of the experimental track were constructed on different subgrades near the town of Singleton, New South Wales, Australia, and then extensively instrumented. Various types of geosynthetics with different mechanical and geometrical properties were installed below the ballast layer. In addition, a shockmat layer was placed (i.e., underneath ballast) on a concrete bridge deck to examine its role in reducing ballast degradation. In other words, this rubber 


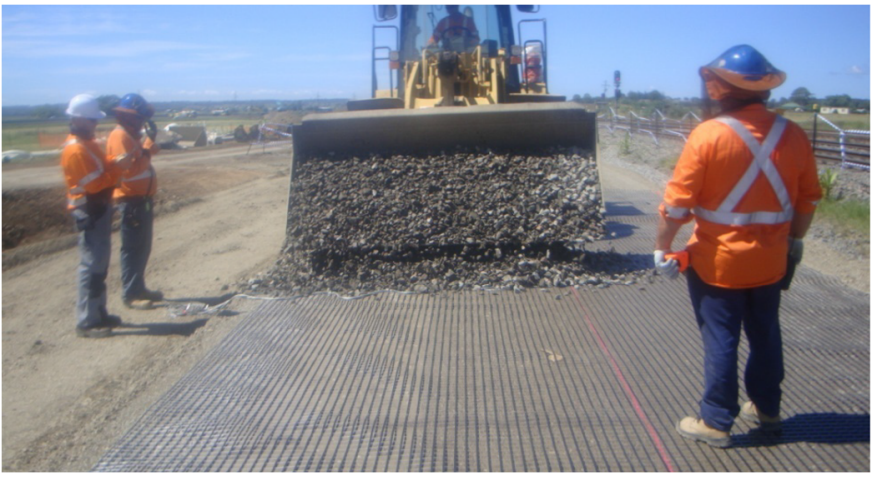

(a)

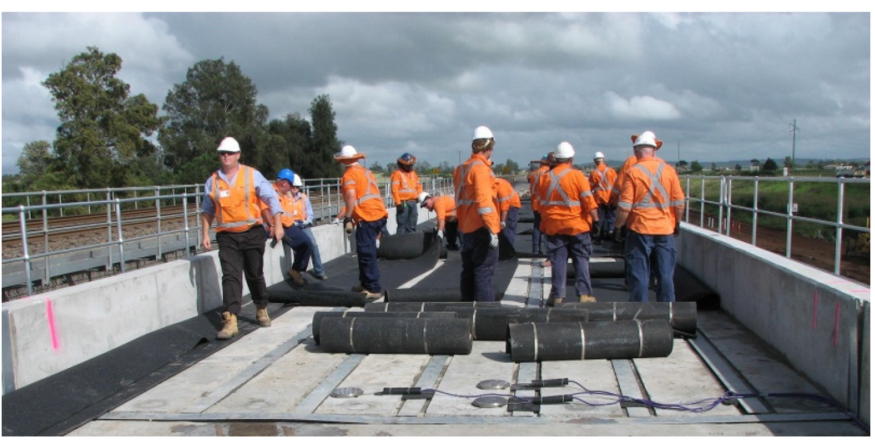

(b)

Fig. 1. (a) Installation of geogrid in track section located on soft alluvial deposit; (b) placement of shockmat on concrete deck of bridge, in the town of Singleton

layer can be considered as an energy absorbing or damping element that decreases the harsh subgrade (concrete) reaction, thereby controlling ballast deformation and damage. Placement of geogrid and shockmat along the Singleton experimental track is shown in Fig. 1. Subsequently, deformation and degradation of the ballast layer, traffic-induced stresses, and strains developed in the geosynthetics under railway traffic were monitored over a five-year period. This paper presents the details of field instrumentation and monitoring and discusses the outcomes of this full-scale trial.

\section{Details of Experimental Track}

\section{Site Layout and Subsurface Exploration}

The experimental sections were part of the Minimbah Bank Stage 1 Line that is owned and operated by the Australian Rail Track Corporation (ARTC). A subsurface exploration program consisting of 33 boreholes, 8 dynamic cone penetration (DCP) tests, and 11 standpipe piezometers was executed (RCA 2008). Three parts of the proposed track on different subgrades were selected to study how the subgrade conditions would affect its performance. The subsurface conditions of these two parts are shown in Fig. 2. In the first part, the top alluvial silty clay was 7-10 m thick, whereas the underlying heterogeneous layer of sand-silty clay was 7-9 m thick. Medium strength siltstone was found beneath the sand-silty clay layer [Fig. 2(a)]. The triaxial testing of samples of alluvial subgrade at depths 1.5 and $4.5 \mathrm{~m}$ yielded (saturated) undrained cohesions of 45 and $120 \mathrm{kPa}$, drained cohesions of 8 and $30 \mathrm{kPa}$, and friction angles of 24 and $23^{\circ}$, respectively (RCA 2008). Data from the borehole indicated that the first part $(234.0-234.8 \mathrm{~km})$ was on the silty clay deposit (Fig. 2). The DCP test results revealed that the upper $0.2 \mathrm{~m}$-thick layer of alluvial clay was somewhat softer but became stiffer with depth.

Data from the borehole indicated that the second part (228.3$228.6 \mathrm{~km}$ ) was on the outcrop of much stronger siltstone (Fig. 2). The particular siltstone of the second part $(228.3-228.6 \mathrm{~km})$ was highly weathered and disintegrated into silty-clayey gravel when exposed, and as such a 'transition' layer of 50-150 mm-thick siltyclayey gravel had formed on the cut surfaces and on top of the 'intact' siltstone [Fig. 2(b)]. The bedrock was a highly weathered siltstone with weak to medium strength (RCA 2008), which was encountered at a depth of about $1-3 \mathrm{~m}$ in the second part. The groundwater was located at a depth of $9 \mathrm{~m}$. The third part (232.0-232.1 km) was entirely on the reinforced concrete deck of Mudies Creek Bridge; a bridge supported by piled abutments.

\section{Track Construction}

Eight experimental sections were included in parts of the three tracks while the track was being constructed. In these sections, different geosynthetics were installed below the ballast layer to study how effectively they improved the overall performance of the track. Section A and Sections 1-4 were located within that part of the track situated on relatively soft general fill and alluvial silty clay [Fig. 2(a)]. Section B was located on the stiff reinforced concrete deck of Mudies Creek Bridge, and Sections C and 5 were on that part of the track on cut siltstone [Fig. 2(b)]. Details of the track substructure are shown in Fig. 3. The track consisted of steel rails (unit mass of $60 \mathrm{~kg} / \mathrm{m}$ ) located on reinforced concrete ties (2,500 $\mathrm{mm}$ long by $260 \mathrm{~mm}$ wide by $230 \mathrm{~mm}$ deep), at $600 \mathrm{~mm}$ spacing (center to center). The ties were embedded $220 \mathrm{~mm}$ into the ballast, which extended about $300 \mathrm{~mm}$ below the ties. The ballast was underlain by a 150-300 mm-thick layer of subballast, below which was a 400-600 mm-thick layer of structural fill. Cuts (blasts) were made into the siltstone outcrop at several locations, and the siltstone cuttings were further crushed and graded to obtain 'ripped' fragments. These materials were used to construct embankments or fills to support and keep the track level for $229.0-234.5 \mathrm{~km}$. The original ground surface at this part of the track was almost $30 \mathrm{~m}$ below the siltstone, so a section of the first part of the selected track (234.0-234.5 km) was underlain by a layer of general fill, as shown in Fig. 3(a). For the remainder of this part, the formation was placed directly onto the deposit of alluvial silty clay. In the second part, the track was constructed above the 'transition' layer [Fig. 3(b)] for the reasons explained earlier. No subballast or structural fill was needed on the deck of the bridge [Fig. 3(c)] to keep the rail level relative to and below the barriers of the bridge.

\section{Material Used in Field Trial}

\section{Ballast, Subballast, Structural Fill, and Subgrade}

The particle size distributions of the ballast, subballast, and structural fill were based on current industry practices (AS 1996), as shown in Fig. 4. The ballast consisted of fragments of angular latite basalt rock, whereas the subballast and structural fill were both sandy gravel, but with different gradations. The ballast, subballast, and structural fill were obtained from the same quarry (Allandale, NSW). The in situ stiffness of the subgrades was assessed by dynamic cone penetration tests (Delaney 2011). Average counts of 12 and 400 blows per $150 \mathrm{~mm}$ depth of penetration were obtained for the alluvial silty clay and the siltstone, respectively. This implied a requirement of about $500 \mathrm{~mm}$-thick structural fill at the soft alluvial deposit (Delaney 2011). 


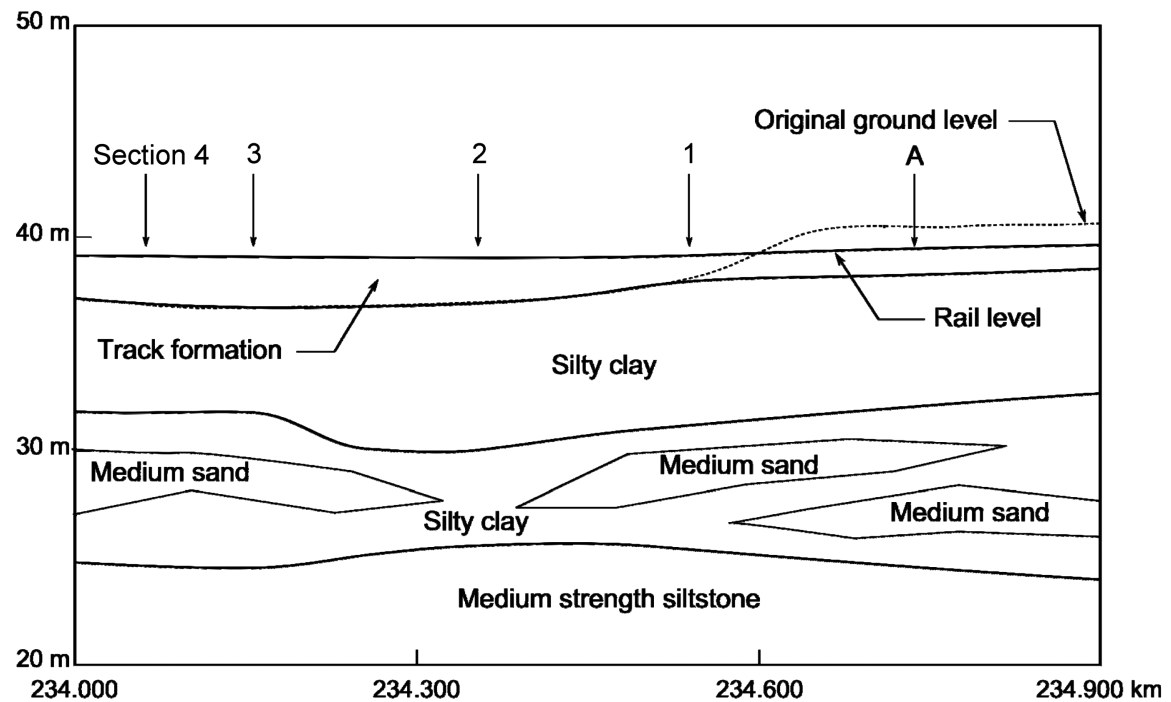

(a)

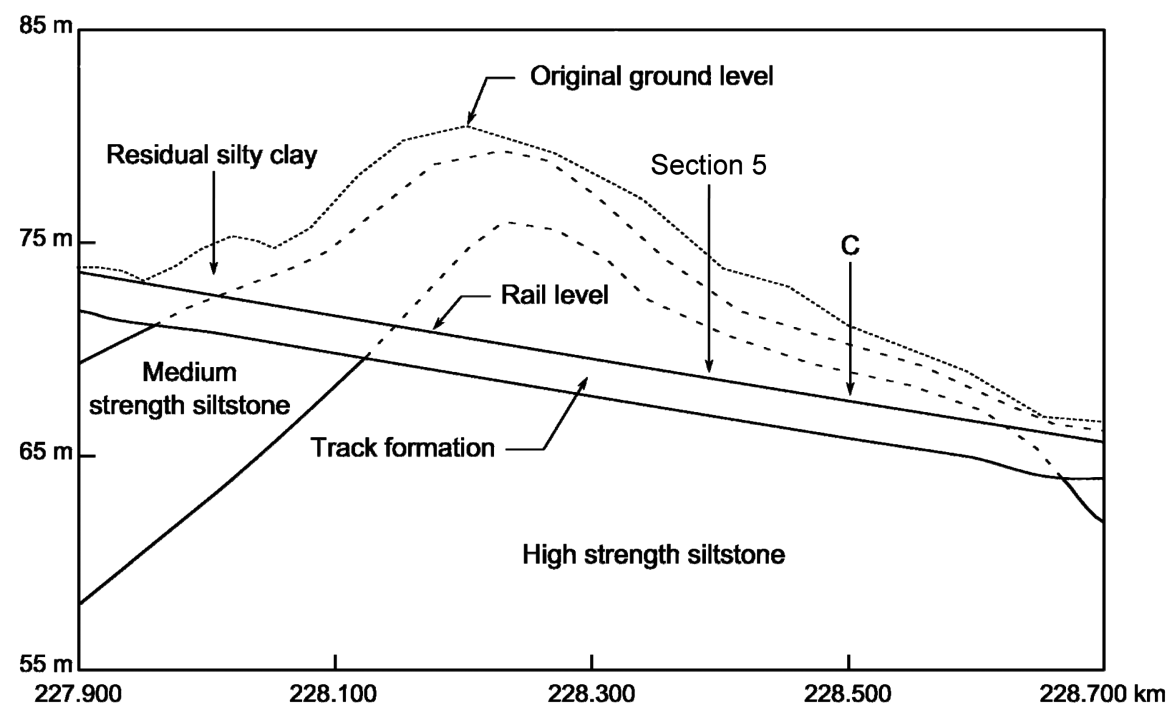

(b)

Fig. 2. Profiles of subsurface conditions for (a) soft alluvial deposit; (b) hard rock

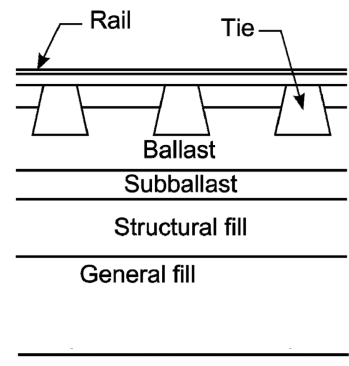

Alluvial silty clay

(a)

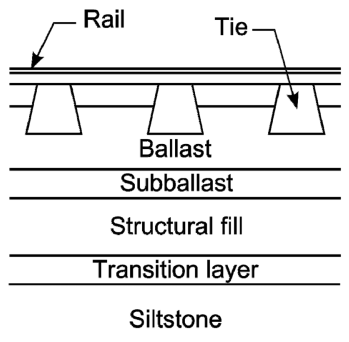

(b)

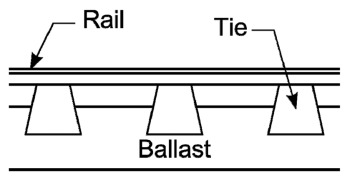

Concrete deck

(c)

Fig. 3. Components of track formation of (a) soft alluvial deposit; (b) hard rock; (c) concrete bridge deck

\section{Geosynthetics and Shockmats}

Three biaxial geogrids (GG-1, GG-2, and GG-3) and one geocomposite (GC-1) formed by biaxial geogrid (GG-4) and nonwoven geotextile (GT-1) were used in this study (Table 1). Single layers of geogrids (GG-1, GG-2, GG-3) were installed at the ballast-subballast interface in Sections 1, 2, and 3, respectively.A single layer of geocomposite (GC-1) was installed at Section 4, and a layer of geogrid (GG-3) was installed at Section 5, but for the purpose of comparison, no geosynthetics were installed at Sections A and C. A layer of shockmat was installed at the ballast-concrete deck interface at 


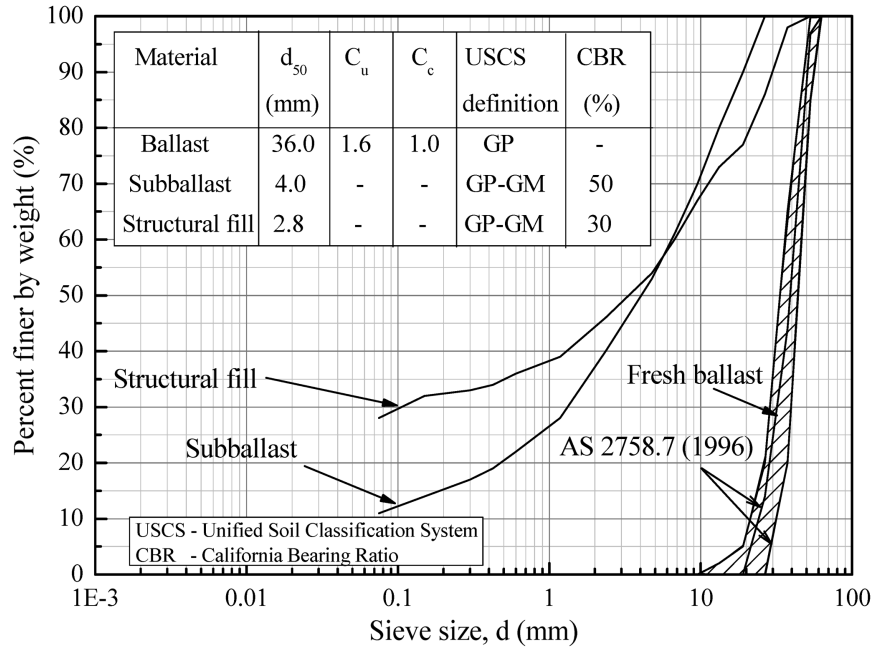

Fig. 4. Particle size distributions of fresh ballast, subballast, and structural fill used in construction of rail track

Section B; these energy-dissipating materials also help to reduce ballast breakage (Nimbalkar et al. 2012). The pertinent physical, mechanical, and geometrical characteristics of geosynthetics and shockmat are given in Tables 1 and 2, respectively.

\section{Field Instrumentation}

To accurately monitor track performance in real time, robust highprecision instruments and data acquisition systems were used (Fig. 5), as described later.

\section{Strain Gauges}

Strain gauges were used to study the longitudinal and transverse strains mobilized in the geogrid (GG-1, GG-2, GG-3) and geocomposite (GC-1) layers. These strain gauges were designed for a wide temperature compensation range from $0^{\circ} \mathrm{C}$ to as high as $+150^{\circ} \mathrm{C}$. These were a postyield type that could measure strains up to $15 \%$ to a very high accuracy irrespective of temperature changes. They were installed in groups, on the top and bottom of the geogrids, in longitudinal and transverse directions, as shown in Fig. 6(a). At each section, groups of four strain gauges were installed at three locations, i.e., below the edge of the tie, below the rail, and near the
Table 2. Index Properties of Shockmat

\begin{tabular}{lc}
\hline Characteristics & Specifications \\
\hline Physical characteristics & \\
Material & Polyurethane elastomer \\
Type & Bonded rubber granulates of $1-3 \mathrm{~mm}$ size \\
Mechanical characteristics & 600 \\
Tensile strength $\left(\mathrm{kN} / \mathrm{m}^{2}\right)$ & 6.12 \\
Young's modulus $(\mathrm{MPa})$ & 80 \\
Strain at break $(\%)$ & 10 \\
Geometrical characteristics & 1,225 \\
Thickness $(\mathrm{mm})$ & \\
Density $\left(\mathrm{kg} / \mathrm{m}^{3}\right)$ & \\
\hline
\end{tabular}

center of the track. The strain gauges were suitably protected from possible damage by aggregates. The surface of the geogrid was cleaned and degreased with rubbing alcohol, a thin layer of cyanoacrylate adhesive was applied onto the surface, and then the strain gauge was attached. After the adhesive had cured, the strain gauge was sealed with a layer of vulcanizing silicone rubber ( $2 \mathrm{~mm}$ thick), followed by another layer of butyl rubber ( $2 \mathrm{~mm}$ thick). Data cables from the strain gauges were routed through flexible aluminum tubes (15 $\mathrm{mm}$ inside diameter) to terminal boxes located at the toe of the granular embankment. The aluminum tubes were extended along the ribs of the grid, with enough slack to account for distortions during the placement of ballast, and any subsequent long-term deformation of the track and geogrids.

The measured data in raw format (voltage, $\mathrm{mV}$ ) was corrected based on the calibration test detailed in ASTM D6637 (ASTM 2001). Following an approach suggested by Bathurst et al. (2002), in this study, the local strains measured from strain gauges were transformed to global strains adopting the appropriate calibration factors $(\mathrm{CF})$ in the range from 1.01 to 1.08 , depending upon the strain levels (varying from 0 to $2.25 \%$ ) and the type of geosynthetics used [polypropylene biaxial geogrid (GG-1, GG-2, GG-3) and geocomposite (GC-1)]. In this study, only up to $2.25 \%$ strain was mobilized. At such relatively low strains, these gauges have proven to be very accurate to determine strains with insignificant time effects (i.e., both loading rate and creep) as noted by Allen and Bathurst (1996). Also, the axle loading was imparted by the passage of trains with a significant $(15-20 \mathrm{~min})$ rest period.

\section{Pressure Cells}

To monitor any transient vertical stresses in the track, rapidresponse hydraulic pressure cells $(230 \mathrm{~mm}$ diameter by $12 \mathrm{~mm}$

Table 1. Index Properties of Geogrids and Geocomposite

\begin{tabular}{|c|c|c|c|c|c|}
\hline Characteristics & Geogrid (GG-1) & Geogrid (GG-2) & Geogrid (GG-3) & \multicolumn{2}{|c|}{ Geocomposite (GC-1) } \\
\hline \multicolumn{6}{|l|}{ Physical characteristics } \\
\hline \multirow{2}{*}{ Material } & \multicolumn{3}{|c|}{ Polypropylene (PP) } & \multicolumn{2}{|c|}{ Polypropylene (PP) } \\
\hline & & & & GG-4 & GT-1 \\
\hline Type & Biaxial & Biaxial & Biaxial & Biaxial & Nonwoven \\
\hline \multicolumn{6}{|l|}{ Mechanical characteristics } \\
\hline Tensile strength at $2 \%$ strain $^{\mathrm{a}}(\mathrm{kN} / \mathrm{m})$ & $14 \times 12.5$ & $11 \times 12$ & $10.8 \times 10.8$ & $16 \times 16$ & $2.5 \times 3.5$ \\
\hline Tensile strength at $5 \% \operatorname{strain}^{\mathrm{a}}(\mathrm{kN} / \mathrm{m})$ & $26.5 \times 25$ & $22 \times 25$ & $21.6 \times 21.6$ & $32 \times 32$ & $4.5 \times 7.5$ \\
\hline Peak tensile strength ${ }^{\mathrm{a}}(\mathrm{kN} / \mathrm{m})$ & $36 \times 36$ & $30 \times 30$ & $30 \times 30$ & $40 \times 40$ & $6 \times 10$ \\
\hline Tensile stiffness ${ }^{\mathrm{a}}(\mathrm{MN} / \mathrm{m})$ & $1.8 \times 1.8$ & $1.5 \times 1.5$ & $1.5 \times 1.5$ & $2 \times 2$ & $0.3 \times 0.5$ \\
\hline Strain at break ${ }^{\mathrm{a}}(\%)$ & $10 \times 10$ & $15 \times 15$ & $15 \times 15$ & $15 \times 15$ & $60 \times 40$ \\
\hline \multicolumn{6}{|l|}{ Geometrical characteristics } \\
\hline Aperture size ${ }^{a}(\mathrm{~mm})$ & $44 \times 44$ & $65 \times 65$ & $40 \times 40$ & $31 \times 31$ & - \\
\hline Thickness (mm) & 3 & 4 & 2.7 & 3 & 2.9 \\
\hline Specific mass $\left(\mathrm{g} / \mathrm{m}^{2}\right)$ & 280 & 330 & 300 & 240 & 150 \\
\hline
\end{tabular}

${ }^{a}$ The values are given as $\mathrm{MD} \times \mathrm{CMD} ; \mathrm{MD}=$ machine direction; $\mathrm{CMD}=$ cross-machine direction . 


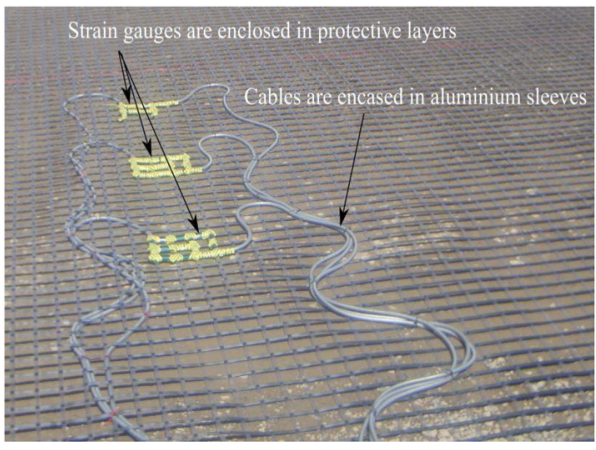

(a)
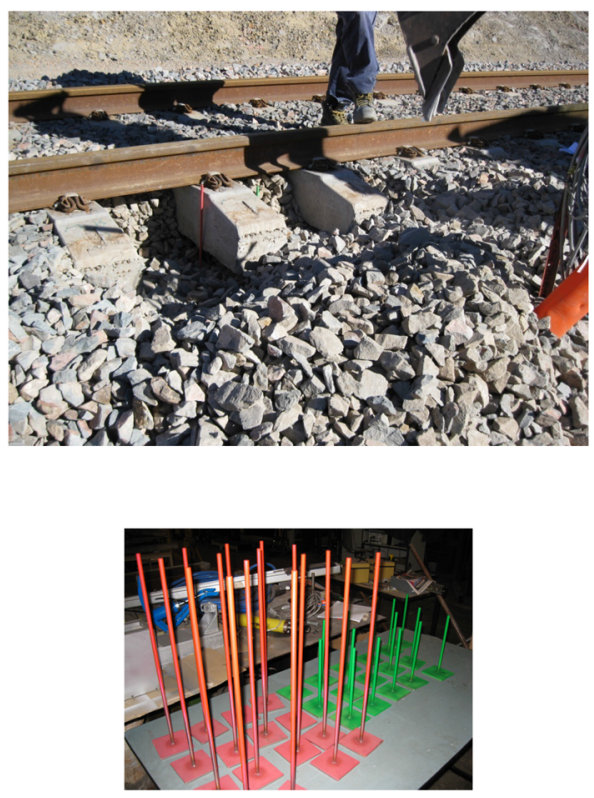

(c)

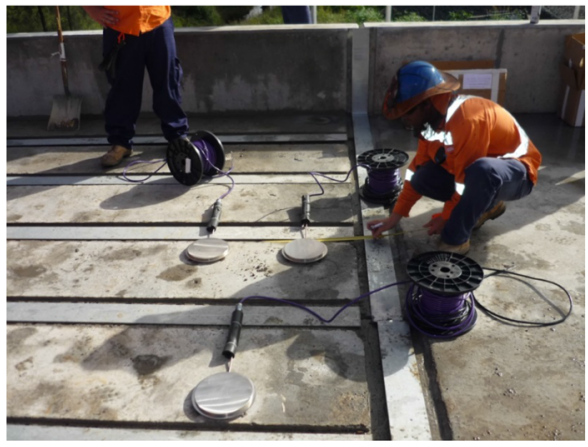

(b)
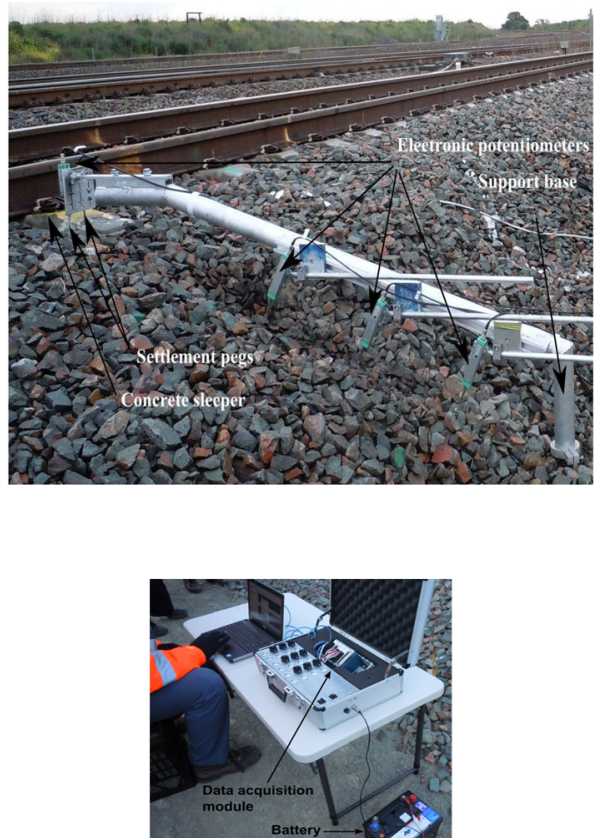

(d)

Fig. 5. Details of instruments: (a) strain gauges; (b) pressure cells; (c) settlement pegs; (d) deformation monitoring frame with computer controlled DAQ module

thick) that could measure stresses up to $600 \mathrm{kPa}$ were used in accordance with the previous study (Indraratna et al. 2010). These pressure cells could be used without losing accuracy (i.e., less than $0.4 \%$ deviation from the original calibration factors) between $-20^{\circ}$ to $+80^{\circ} \mathrm{C}$ as verified in the past study (Indraratna et al. 2010). Two pressure cells were installed at Sections A, 1, C, and 5, and at each section, one pressure cell was installed below the rail at the tieballast and another at the ballast-subballast interface [Fig. 6(b)]. To install these pressure cells, ballast was excavated to the subballast, the bottom pressure cells were placed in position, and then the ballast was backfilled. The top pressure cells were inserted underneath the concrete ties. Care was taken to ensure full contact between the pressure cells and the ties, the ballast, and the subballast, to avoid erroneous readings of stresses. At Section B, three pressure cells were installed below the shockmat, and below three consecutive ties. While the track was being constructed, three pressure cells were placed on the concrete deck of Mudies Creek Bridge, and then covered by the shockmat before the ballast was laid down.

The contact condition between the tie and pressure cells can affect the accuracy of measurements. The calibration of pressure cells has been conducted thoroughly at the tie-ballast interface recognizing the effects of rigid body inclusion on contact stress measurement, as vividly described by Rose et al. (2004) and Anderson and Rose (2008). In accordance, the large-scale process simulation test apparatus designed and built in house $(800 \times$ $600 \times 600 \mathrm{~mm}$ ) (Indraratna and Nimbalkar 2013) was used to assemble a prototype track segment to calibrate the pressure cells at the tie-ballast interface, thereby correctly simulating the appropriate loading and substructure conditions prevailing at the site including the correct placement densities of substructure materials. The calibration tests for the pressure cells were conducted following the method described by Talesnick (2005), further extending past approaches (e.g., Weiler and Kulhawy 1982; Dunnicliff 1988; Clayton and Bica 1993). The cell output at zero pressure was recorded before installation and load application. The output voltage of the pressure sensors under different loads were then obtained and used in the calibration process. The measurements made at the tie-ballast interface were also compared to the computed values obtained from an established stress analysis program, specially developed in house for Australian railway conditions using MATLAB 7.9.1 following the well-known theoretical approach proposed by Jeffs and Tew (1991). 


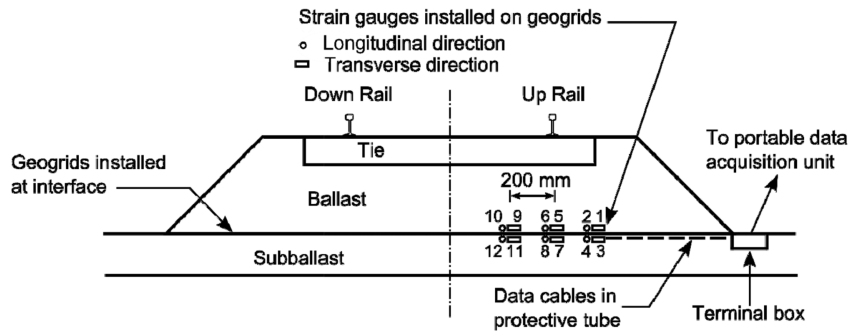

(a)

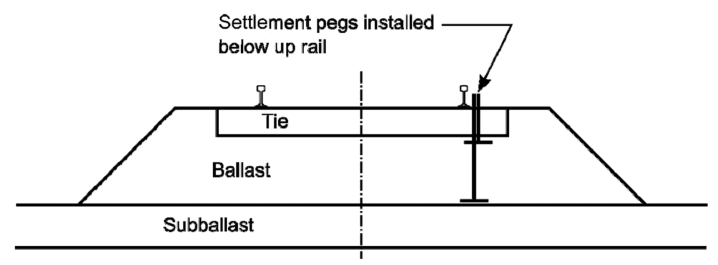

(c)

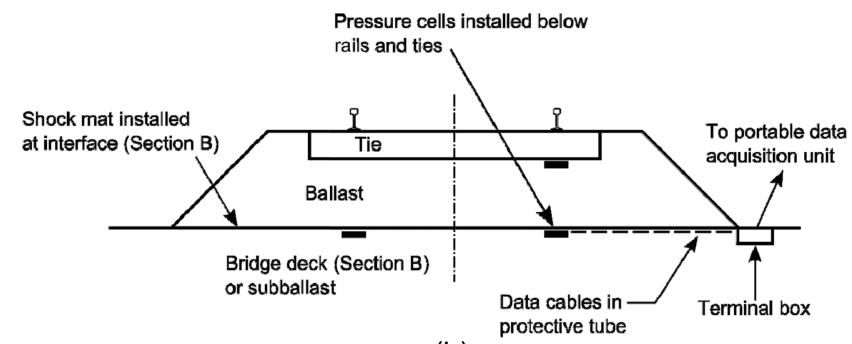

(b)

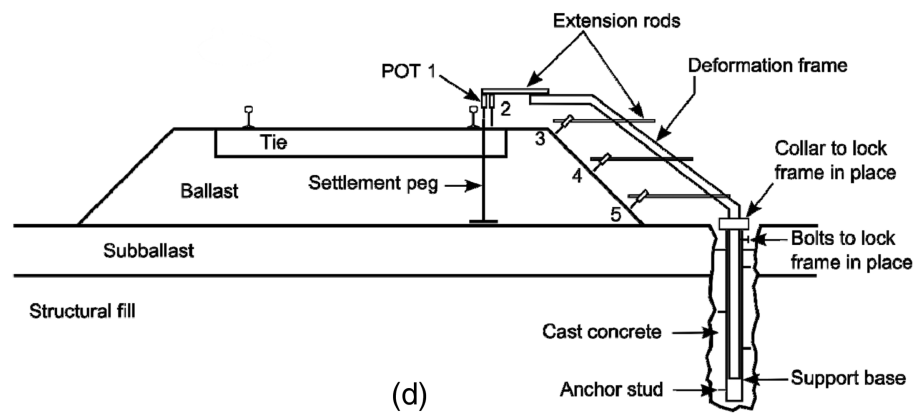

Fig. 6. Details of track instrumentation using: (a) strain gauges; (b) pressure cells; (c) settlement pegs; (d) deformation monitoring frame

\section{Settlement Pegs}

Settlement pegs were installed to measure any vertical deformation in the layers of ballast and subballast. These settlement pegs consisted of $100 \times 100 \times 6 \mathrm{~mm}$ stainless steel base plates attached to $10 \mathrm{~mm}$ diameter vertical indicator rods with lengths to match the embedding depths in the track. The settlement pegs were installed at the tie-ballast and ballast-subballast interfaces at every section [Fig. 6(c)], except at Section B. The pegs were located adjacent to ties to minimize disturbance from routine track tamping. Placing the settlement pegs involved removing and backfilling the ballast, similar to the installation of pressure cells.

\section{Displacement Monitoring Frame}

Transient deformation of the ballast in both vertical and horizontal directions was measured by linear variable differential transformers (LVDTs) mounted on a custom made frame, as shown in Fig. 6(d). These LVDTs were calibrated in house by technical staff, by correlating the electrical outputs (i.e., voltage, V) of the LVDTs with the micrometer readings which ensured a linear differential trend as expected. The linear calibrations obtained were then compared to those provided by the supplier as an additional verification check (usually they were very close). The influence of temperature to output voltage was less than $1.5 \mathrm{ppm} /{ }^{\circ} \mathrm{C}$ for the designed temperature range from -30 to $+100^{\circ} \mathrm{C}$. In brief, the fluctuation of temperature during this 5 year study was relatively small and well within the specified accuracy (design) range of all sensors employed in this study, and therefore, the measured data are very reliable and free of temperature effects. The frame was made from $80 \mathrm{~mm}$ outside diameter by $10 \mathrm{~mm}$ wall thickness aluminum tubes. Two LVDTs [labelled as POT 1 and 2 in Fig. 6(d)] were installed in a vertical direction on an extension rod that can slide horizontally, relative to the tip of the frame. LVDT 1 measured the vertical movement of the ties, while LVDT 2 measured vertical movement by the ballastsubballast settlement pegs. The other three LVDTs [labelled as 3,4 , and 5 in Fig. 6(d)] were mounted at a $45^{\circ}$ angle, on extension rods located at different elevations [Fig. 5(d)] in order to record deformations on the surface of the shoulder ballast. These additional deformations of shoulder ballast were taken in order to assist the track crew in maintaining the proper shoulder ballast profile as required by the Australian Rail Track Corporation (ARTC) (track owner). These deformations relevant to ballast shoulders are not important to the field data plotted in this paper; hence, they are not presented here. The frame was held in place by support bases made from studded stainless steel tubes $(92 \mathrm{~mm}$ outside diameter, $800 \mathrm{~mm}$ long, and $10 \mathrm{~mm}$ wall thickness) that were sealed at the bottom ends. These support bases were installed in $200 \mathrm{~mm}$ diameter by $850 \mathrm{~mm}$ deep holes drilled into the layer of subballast by a handheld auger. The support bases were also placed in the holes, and then quick-set concrete was cast around them. The support bases were aligned with a precision level before the concrete could set. The deformation frame was designed to ensure there was enough clearance between the two vertical LVDTs and passing trains.

\section{Humidity Effects}

Clean ballast is a free draining material, and because this is a relatively new track (five years since construction), fouling was found to be insignificant. Free-draining ballast would not retain moisture in open track in Singleton, i.e., $80 \mathrm{~km}$ away from the coast, and it is not a location where there is regular rainfall, but is usually characterized by a dry weather pattern most of the year with a generally low and relatively stable humidity in the proximity of $40 \%$ as recorded by the site weather station. Therefore, on the track, the moisture content of the ballast layer rarely exceeded 6-7\%. Even after brief spells of wet weather, the correspondingly elevated moisture content would rapidly decrease soon after the rainfall event.

\section{Data Acquisition}

Data from the strain gauges, pressure cells, and LVDTs were obtained in real time by a mobile data acquisition system, which operated at a frequency of $2 \mathrm{kHz}$ and was triggered manually. For a train speed of $60 \mathrm{~km} / \mathrm{h}$, a wheel could travel a distance of $0.4 \mathrm{~m}$ in $1 / 40$ th of a second. It cannot therefore be ascertained that any wheel would be over the instrumented sleeper at the time of recording 


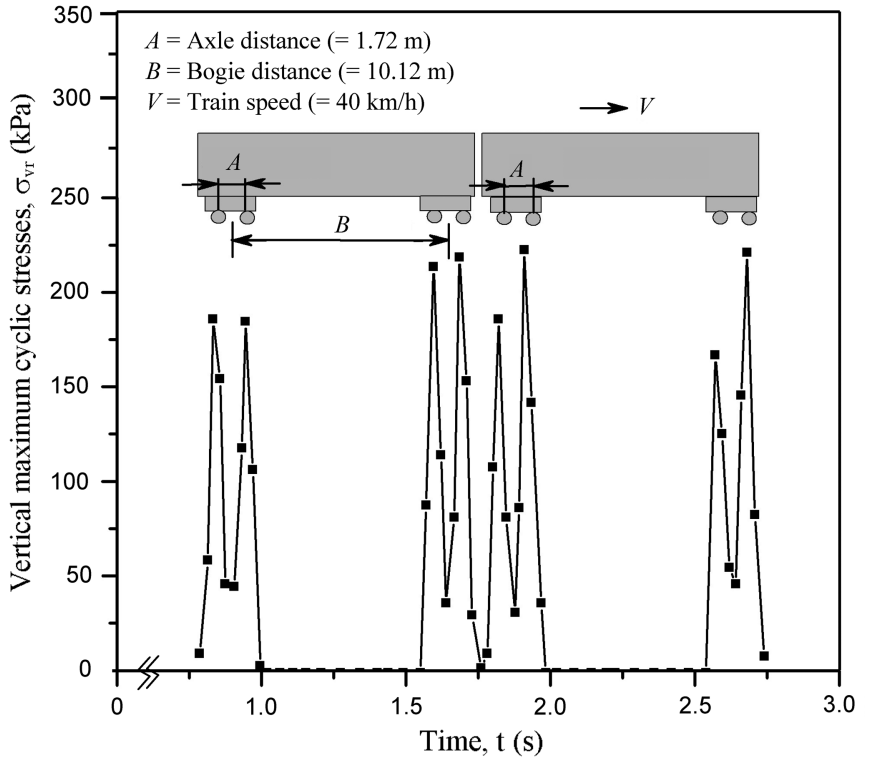

Fig. 7. Schematic illustration of measurement of pressure under the tie due to the passage of a coal train ( $25 \mathrm{t}$ axle load) (data from Sun et al. 2015)

using the data acquisition system operating at a maximum frequency of $40 \mathrm{~Hz}$. Considering these limitations, a more advanced data acquisition system was used in this field trial to obtain data from the aforementioned instruments at a frequency of $2 \mathrm{kHz}$. The settlement pegs were monitored using a survey technique. Because the data was measured against time, a more appropriate 'number of load cycles' scale rather than a 'time' scale was used. In this study, the load cycles were considered as the number of axle passes rather than the number of wagon passes based on a time history plot of the dynamic soil stress recorded in the ballast layer as shown in Fig. 7. This is because a typical freight wagon often has multiple axles (e.g., four axles) that impart individual load cycles and an axle distance of about $1.72 \mathrm{~m}$ (Indraratna et al. 2014b; Sun et al. 2015).

\section{Experimental Results}

\section{Long-Term Deformations of Ballast}

The deformation of ballast was determined by subtracting the vertical displacement of the ballast-subballast interface from the tieballast interface. Vertical strain was the ratio of ballast deformation to its initial thickness. A typical example of the vertical deformation $\left(S_{V}\right)$ and strains $\left(\varepsilon_{V}\right)$ plotted versus the number of load cycles $(N)$ is shown in Fig. 8. Track tamping was carried out at about $1.04 \times 10^{6}$, $3.76 \times 10^{6}$, and $1.12 \times 10^{7}$ load cycles. The potential deformation curve after track tamping is also shown. This curve is a projection back to "zero deformation" based on extrapolation of data on the deformation curve. For individual tamping cycles, the deformation of ballast under cyclic loading curves was nonlinear and appeared to increase rapidly within the first $10^{4}$ load cycles, and then increase later at much smaller rates. A similar pattern for the vertical deformation of ballast versus the number of load cycles was observed in a number of large-scale model tests (Raymond and Bathurst 1994; Indraratna et al. 2005; Aursudkij et al. 2009; Indraratna and Nimbalkar 2013). When ballast deformation during consecutive tamping operations was compared, the amounts and rates of increase had decreased, which indicated that deformation
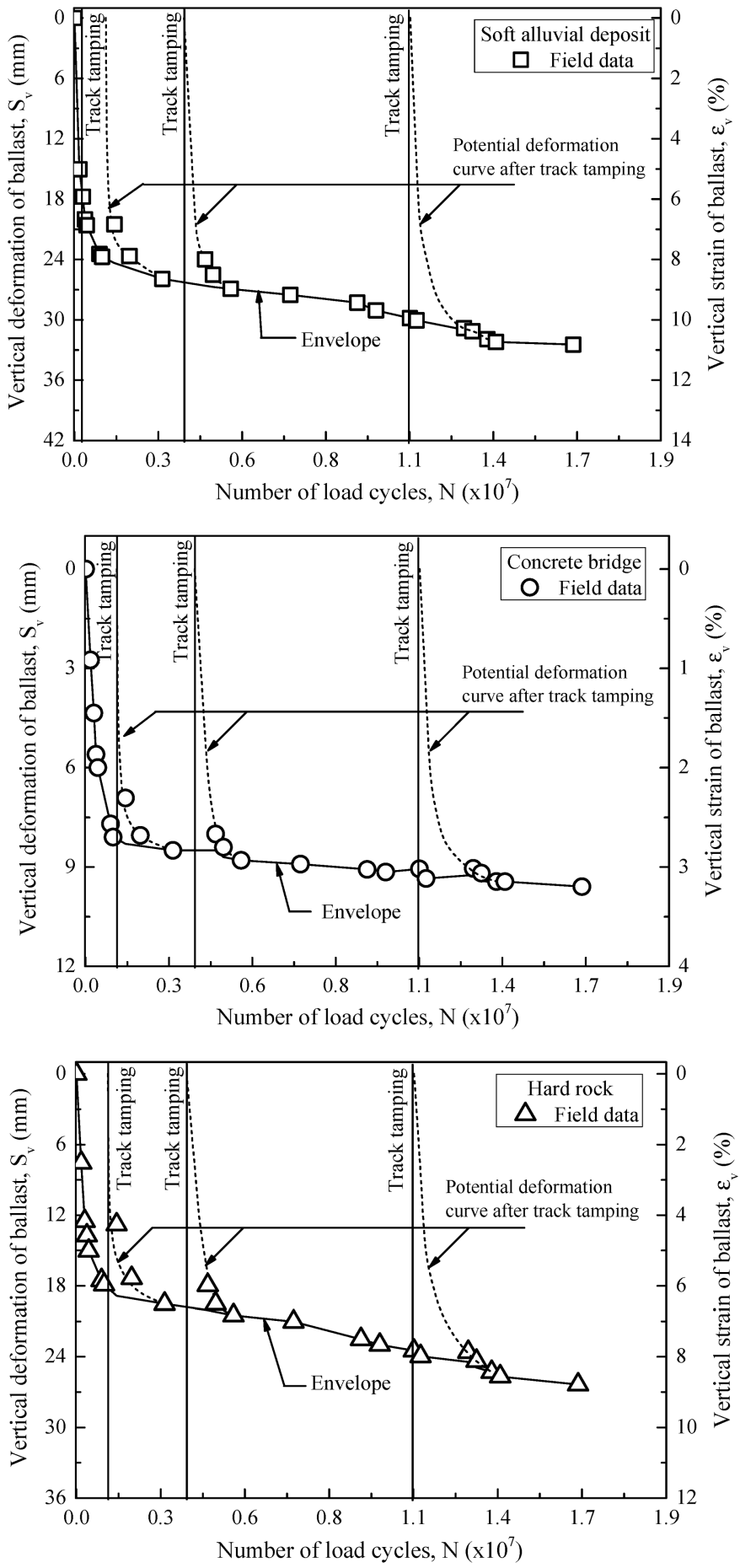

Fig. 8. Relation between vertical deformation of ballast layer and number of load cycles obtained from soft alluvial deposit, concrete bridge deck, and hard rock

was influenced by the condition of the track prior to tamping. This observation was consistent with earlier studies (Selig and Waters 1994; Esveld 2001; Audley and Andrews 2013). In order to incorporate the effect of tamping, the relationship between cumulative vertical deformation $\left(S_{V}\right)$ and the number of load cycles $(N)$ can be empirically modelled as

$$
S_{V}=\sum_{i=1}^{N_{T}}\left(S_{V i}-S_{T i}\right)
$$


in which $S_{T i}=$ amount the track lifted during tamping; $N_{T}=$ number of tamping cycles; and $S_{V i}=$ deformation of ballast between any two consecutive tamping cycles, which can be conveniently obtained as (Indraratna and Salim 2003)

$$
S_{V i}=c_{i}+d_{i}\left(\ln N_{i}\right)
$$

in which $c_{i}$ and $d_{i}=$ two empirical constants. An alternate approach to compute $S_{V i}$ can be expressed as (Indraratna and Nimbalkar 2013)

$$
S_{V i}=S_{1 i}\left(1+a_{i} \ln N_{i}+0.5 b_{i} \ln N_{i}^{2}\right)
$$

in which $S_{1 i}=$ deformation of ballast after the first load cycle; and $a_{i}$ and $b_{i}=$ two empirical constants. At a large number of load cycles, the deformation curves have practically merged into a single curve, thus forming a unique relationship or "envelope" of vertical deformation of the ballast layer and the number of load cycles. Similarly, such "envelopes" of vertical deformation were established for other experimental sections, and are shown in Figs. 9(a and b). In a subsequent development, ballast settlement was evaluated based on the patterns of these envelopes.

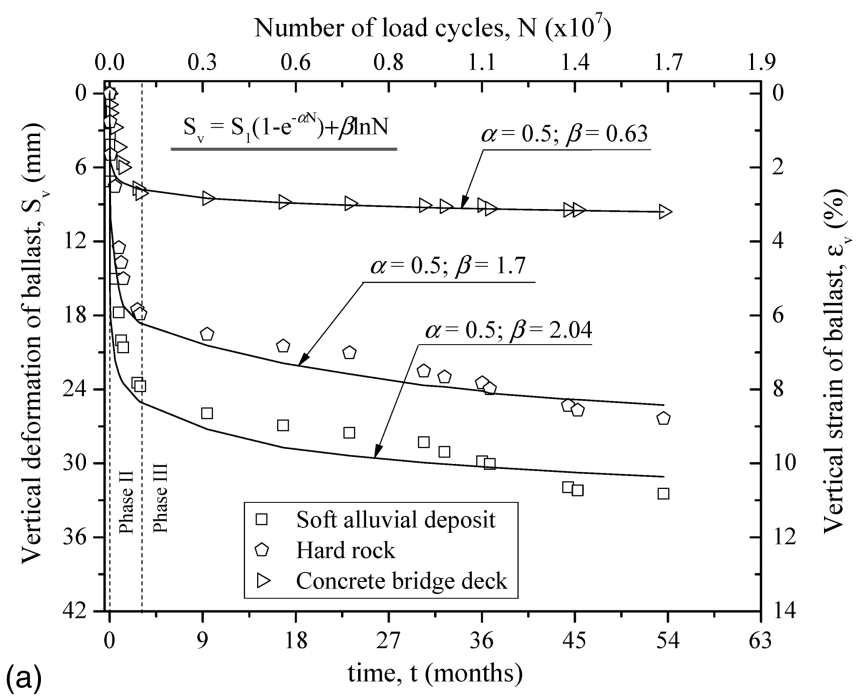

(a)

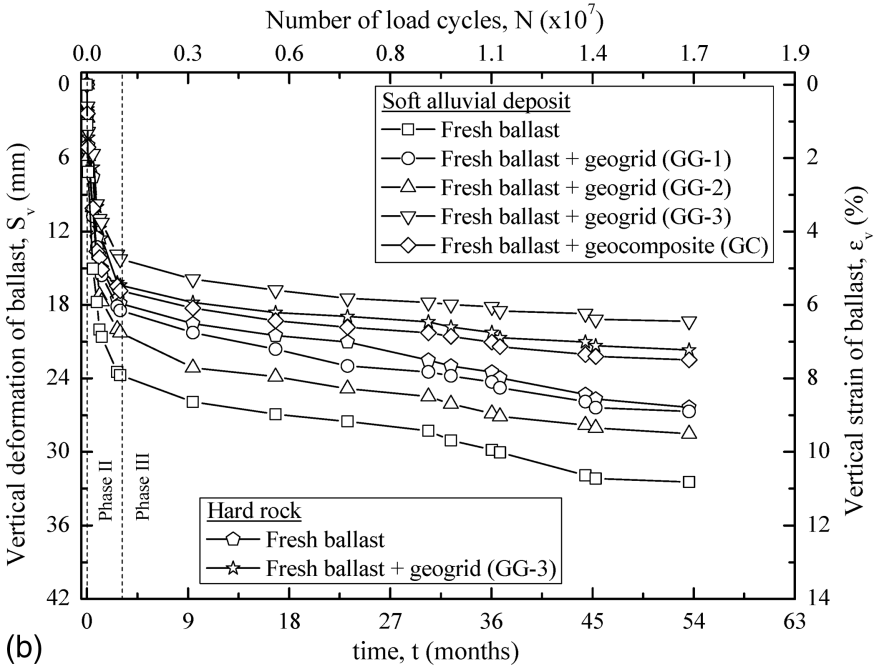

Fig. 9. Vertical deformations and strains of ballast layer plotted versus number of load cycles for (a) varying subgrade types; (b) varying reinforcement types
Vertical deformation of the ballast may be characterized by three phases, regardless of the conditions of the subgrade and the type of reinforcement. Phase 1 was immediate settlement under the first loading cycle, Phase 2 was an unstable zone where deformation increased rapidly initially but then increased at much smaller rates during the third phase. The unstable zone was mainly attributed to the densification of ballast particles under cyclic wheel loads, which resulted in denser packing of the granular layer. In Phase 3, however, further particle rearrangement occurred much less within the now sufficiently packed or stabilized ballast layer. This only resulted in a marginal increase of vertical deformation that could be characterized as "stable shakedown" (Sun et al. 2014). The relationship between vertical deformation and the number of load cycles can be empirically modelled as

$$
S_{V}=S_{1}\left(1-e^{-\alpha N}\right)+\beta \ln N
$$

in which $S_{1}=$ deformation of ballast after the first load cycle; $\alpha$ and $\beta=$ rates of increase in deformation in the unstable and stable zones, respectively. The first term of Eq. (4) refers to settlement due to the first cycle, the second to an unstable zone where $N<6.0 \times 10^{5}$ cycles, whereas the third term refers to a stable shakedown zone where $N>6.0 \times 10^{5}$ cycles [Figs. 9(a and b)].

Fig. 9(a) compares the vertical deformation in the experimental sections with no reinforcement for different types of subgrade. The vertical deformation increased quite rapidly and became larger (at similar numbers of load cycles) when the track was situated on softer subgrade, i.e., vertical deformation was smallest on the deck of the concrete bridge and largest where the track was located on silty clay. The relatively small deformation at Mudies Creek Bridge resulted, in part, from the ballast contained within the barriers of the bridge and where the shockmat was placed, which resulted in insignificant lateral spreading of ballast. At other Sections, however, the ballast was allowed to expand more freely in the horizontal direction (parallel to the sleepers), and this caused larger vertical movement.

The vertical deformation of ballast with geogrid reinforcement was $5-35 \%$ smaller than that without reinforcement [Fig. 9(b)]. This behavior was also observed in the laboratory (Göbel et al. 1994; Indraratna and Salim 2003; Indraratna and Nimbalkar 2013) and other full-scale tests (Fernandes et al. 2008; Indraratna et al. 2010), and can mainly be attributed to the additional internal confinement provided by interlocking between ballast and geogrids. When the results of experimental sections with similar geogrids (i.e., GG-3) but different subgrade conditions were compared, it was noted that a reinforcing geogrid was better at reducing ballast deformation on soft subgrade. These findings agreed with the results of large-scale laboratory tests reported by Ashmawy and Bourdeau (1995). Furthermore, GG-3 generally performed most effectively in terms of reducing ballast deformation due to its optimum size aperture ( $40 \mathrm{~mm}$ or $1.1 d_{50}$ ) which enabled more effective interlocking between the aggregates and grids, and also increased the interface friction. The aperture of GG-2 (65 mm or $\left.1.8 d_{50}\right)$ was too large to allow effective interlocking with the ballast gradation that is typically used in Australia.

\section{Long-Term Strains of Geogrid}

Typical examples of the strains accumulated in the reinforcing geogrids versus the number of load cycles are shown in Fig. 10. Here the strains were obtained from the transverse and longitudinal strain gauges attached to the bottom of the grids and located below the edges of the ties. The results indicated that the transverse $\left(\varepsilon_{g t, \text { cyc }}\right)$ and longitudinal $\left(\varepsilon_{g l, \mathrm{cyc}}\right)$ strains generally increased with the number of load cycles, which suggested there was an accumulation of 

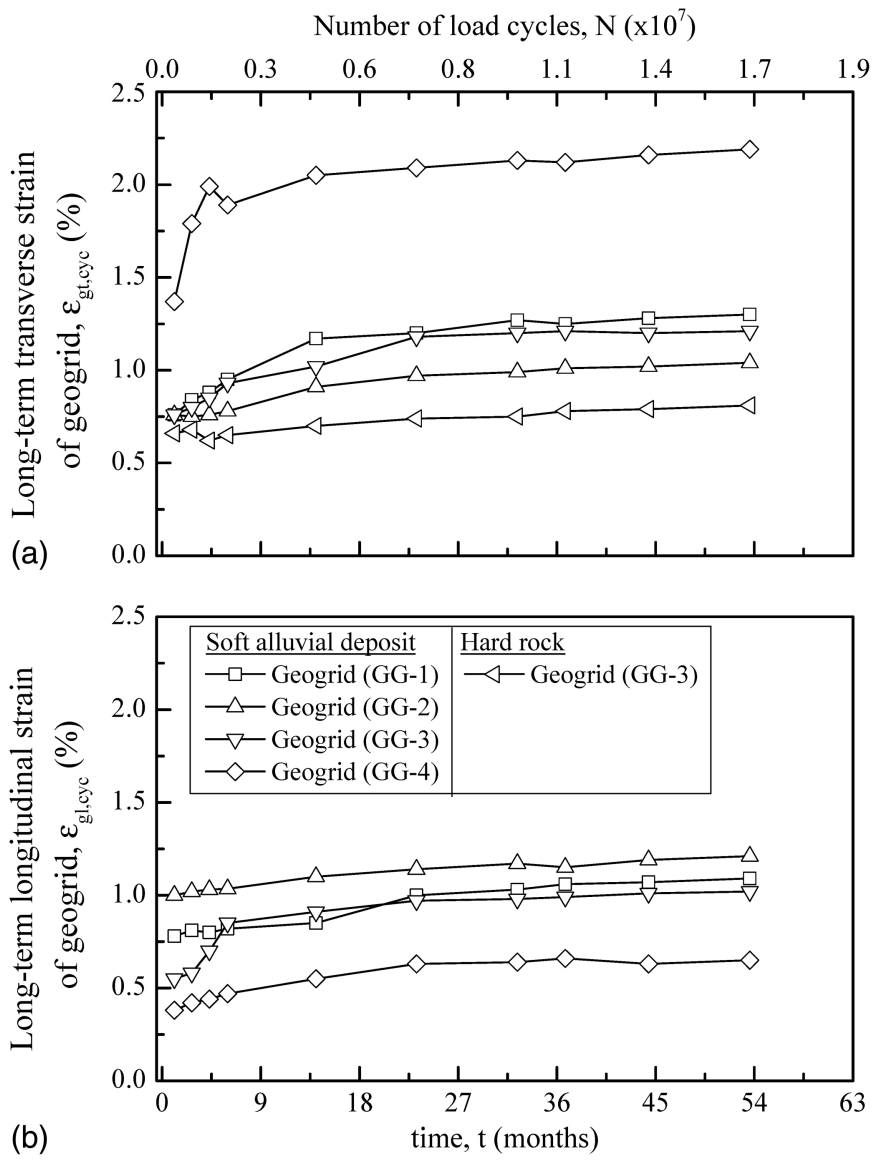

Fig. 10. Strains accumulated in geogrids in (a) transverse; (b) longitudinal directions versus number of load cycles

permanent deformation in the geogrids. Moreover, most of the strains in both directions probably occurred while the experimental sections were being constructed, particularly when the ballast was placed, because it may have pushed the geogrids into depression bowls on the subballast layer, creating initial tensile strains between 0.3 and $2.2 \%$ within the reinforcing layers [Figs. 10(a and b)]. The longitudinal strains appeared to be larger than zero in all cases, which suggested that the conditions of plane strain were not strictly adhered to within the ballast layer in the longitudinal direction.

The transverse strains were generally larger and increased more rapidly with the number of load cycles. After $6.8 \times 10^{6}$ load cycles, the strains in the reinforcing geogrids increased by $0.1-1.0 \%$ in the transverse direction and $0.1-0.5 \%$ in the longitudinal direction. The larger transverse strains are the result of the relative ease with which the ballast was able to spread outward because of less track constraint in that direction. The results in Fig. 10(a) also indicate unusually large strains in the GG-4 that can be attributed to the large lateral strain (1.3-2.0\%) exhibited by the silty clay, shortly after the track was commissioned.

\section{Dynamic Amplification Factor}

In conventional practice, the dynamic amplification factor (DAF) is used as a function of static (wheel) stress and train velocity to obtain the equivalent dynamic stress ( $\mathrm{Li}$ and Selig 1998; Esveld 2001). In the present study it was used to study the possible implications that increased train speeds and axle loads would have on the ballast contact stresses. Fig. 11(a) shows the measured dynamic deviator stress $\left(\sigma_{v, \text { cyc }}^{\prime}\right)$ below the sleeper as a function of train
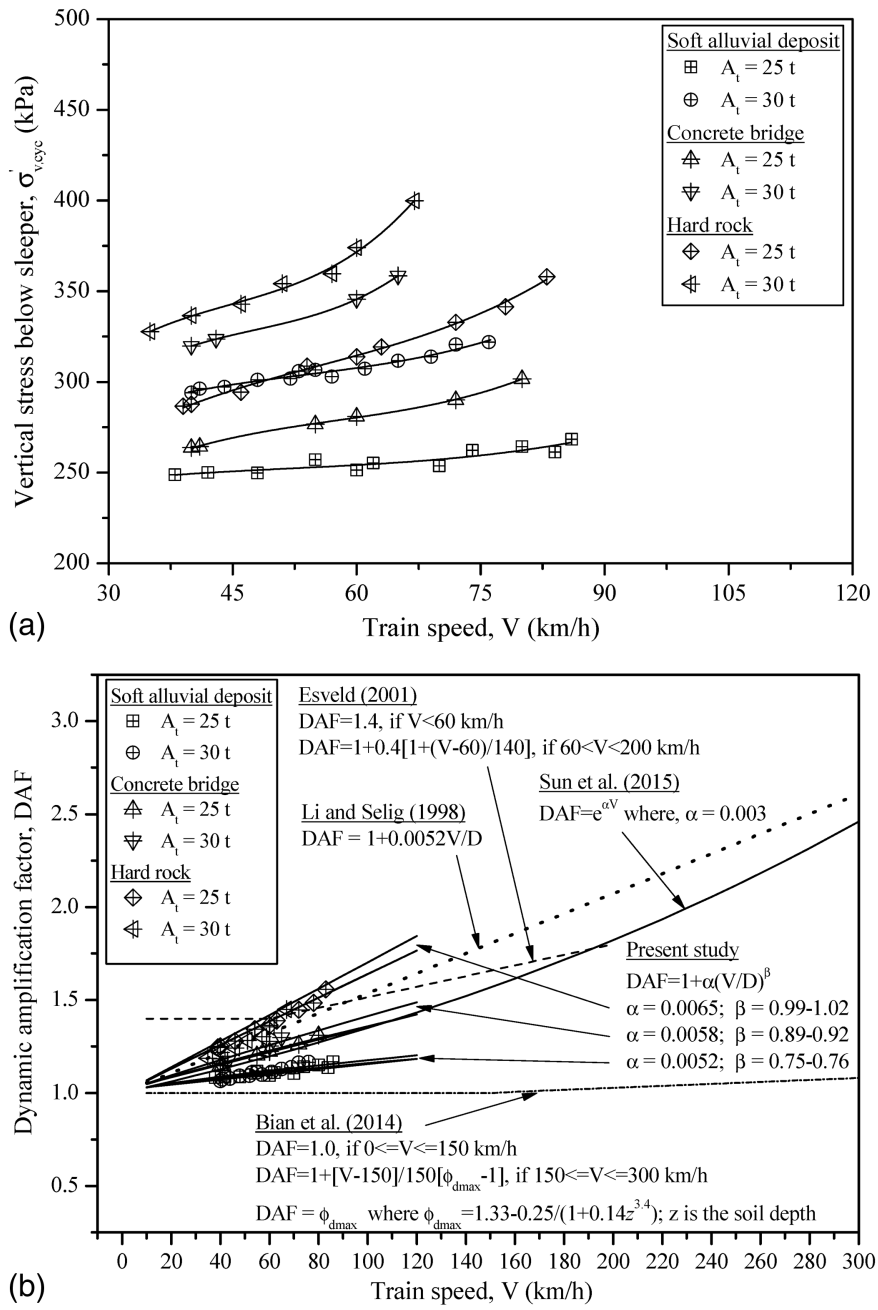

Fig. 11. (a) Measured dynamic vertical stress; (b) dynamic amplification factor (DAF) as a function of train speed $(V)$

speed $(V)$ and the axle load, and as anticipated, an increase in the magnitude of the axle load induced a higher $\sigma_{v \text {,cyc }}^{\prime}$. Moreover, higher train speeds increased $\sigma_{v, \text { cyc }}^{\prime}$, a finding that agreed with other previous studies (Luo et al. 1996; Yang et al. 2009). At Section A, as $V$ increased from 40 to $80 \mathrm{~km} / \mathrm{h}, \sigma_{v, \text { cyc }}^{\prime}$ increased by about $10 \%$ for the same axle load (i.e., $A_{t}=25 \mathrm{t}$ ). This amplification is characteristic of the inherent dynamic response of a granular assembly that densifies during cyclic loading and often causes inevitable degradation in the process (Krylov 2001; Sun et al. 2015). The amplification effects were more pronounced for a track located on hard rock than that located on soft alluvial deposit [Fig. 11(a)]. Thus, the dynamic amplification was directly influenced by variations in the axle load, type of subgrade, and train speed.

In this study, the DAF was calculated using DAF $=\sigma_{v, \text { cyc }}^{\prime} / \sigma_{v \text {,sta }}^{\prime}$, where $\sigma_{v, \text { cyc }}^{\prime}$ is the measured dynamic deviator stress due to a moving train [Fig. 11(a)], and $\sigma_{v \text { sta }}^{\prime}$ is the static stress generated when the train is stationary, which was obtained by Jeffs and Tew (1991):

$$
q_{\mathrm{max}, \mathrm{cyc}}=\left(\frac{3 Q}{B L}\right) F
$$

in which $Q=$ maximum rail seat load (e.g., for a $25 \mathrm{t}$ axle load, $Q=0.4 \times 25,000 / 2 \times 10=50,000 \mathrm{~N}) ; B=$ width of the tie $(0.26 \mathrm{~m}) ; L=$ length of the tie $(2.5 \mathrm{~m})$; and $F=$ factor depending on the type of tie and track maintenance ( $F=1$, for a new track). 
Therefore, $\sigma_{v \text {,sta }}^{\prime}$ is determined as 231 and $277 \mathrm{kPa}$ corresponding to axle loads of 25 and $30 \mathrm{t}$, respectively. Fig. 11(b) illustrates the calculated DAF as a function of train speed $V$, together with the predictions made from other studies (i.e., Li and Selig 1998; Esveld 2001). The conventional approaches over-predicted the value of DAF within its range of application (i.e., $V \leq 100 \mathrm{~km} / \mathrm{h}$ ). This had serious consequences in the design, rendering it costly and overconservative. Therefore, based on the field data, the DAF can be expressed in the form of a non-linear best-fit equation

$$
\mathrm{DAF}=1+\alpha\left(\frac{V}{D}\right)^{\beta}
$$

in which $\alpha$ and $\beta=$ empirical parameters influenced by the axle load and the type of subgrade. Its value is determined using a non-linear regression $\left(R^{2}>0.98\right)$ and is shown in Fig. 11(b).

In full-scale model tests, the dynamic stresses measured below the concrete slab in ballastless tracks could vary in the range 13$20 \mathrm{kPa}$ (Bian et al. 2014). These stresses are significantly lower compared to those observed in this ballasted field study (250$400 \mathrm{kPa}$ ), which could obviously be attributed to the discrete sleepers (ties) spaced typically at $0.6 \mathrm{~m}$ intervals (i.e., discontinuous supports unlike a continuous track). Also, compared to a ballastless track, the dynamic amplification effect is more pronounced in the ballasted track as evident from Fig. 11(b). Also, ballast particles undergo a higher degree of breakage resulting from more intensive dynamic loading imparted by moving trains (Sun et al. 2015).

\section{Dynamic Track Modulus}

One important parameter for characterizing the condition of the track substructure is the track stiffness or modulus. The traditional way of testing the track modulus was to measure the first deflection without a load whilst it was stationary, and then increasing the load to get a load-deflection curve at a given point in the track (Selig and Waters 1994). Field techniques to measure the track modulus also exist: (1) under a stationary train; (2) under a specially adopted vehicle; and (3) under a moving train (Priest and Powrie 2009). Measuring the transient tie displacements along the track gives a measure of the stiffness of the substructure, while assuming that the superstructure is the same (Ebersöhn and Selig 1994). The deformation frame shown earlier in Fig. 6(d) was used to monitor the traffic-induced movement of ties $\left(s_{t t}\right)$. The transient vertical movements of ties were plotted against axle load and train speed in Fig. 12(a). The peak movements of ties at the alluvial deposits were much higher than those at the hard rock. At soft alluvial deposit, the peak movement of ties supported by ballast with GG-3 was about 40-65\% smaller than those supported by ballast without any reinforcement [Fig. 12(a)]. At the hard rock, however, there were differences of about $15 \%$ between the ballast with and without reinforcement, whereas the transient movements were slightly larger for the concrete deck than the hard rock, which was attributed to the placement of shockmats. The value of $s_{t t}$ observed for the case of the concrete bridge (i.e., Fresh ballast + shockmat) is comparable with the case of hard rock (i.e., Fresh ballast) as both these cases belong to the same category (i.e., stiff foundations). These are favorable practical results that would also have significant implications on ride quality and safety at increased speeds.

In this study the track modulus was determined at discrete points along the track during normal scheduled train operations, following the theoretical approach used by Priest and Powrie (2009), because the measurement of loading magnitude and frequency relevant to in-service conditions could be obtained. By considering the track as a continuous beam resting on an elastic foundation, the differential
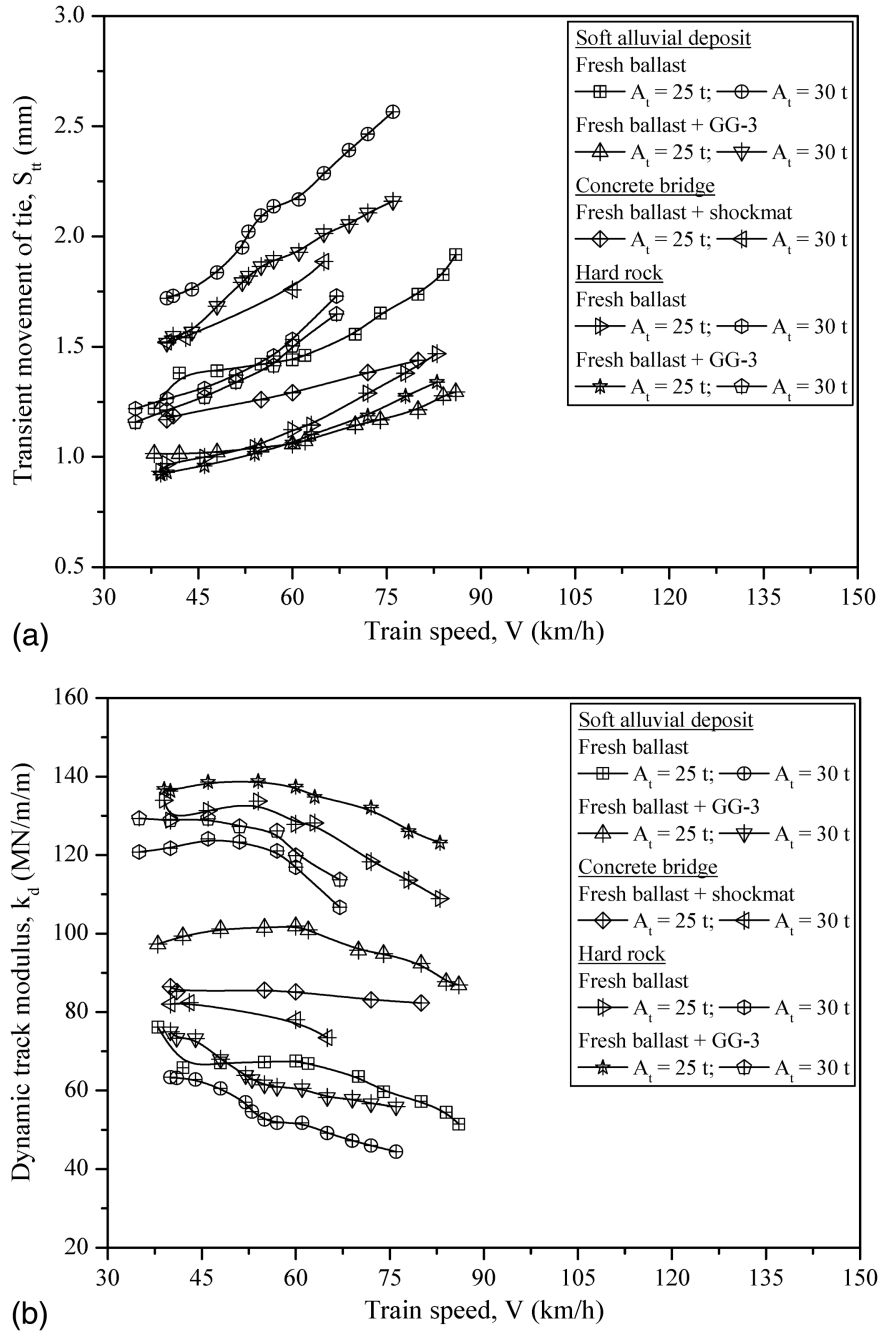

Fig. 12. (a) Measured transient displacement of tie; (b) dynamic track modulus as a function of train speed $(V)$

equation for the displacement of the beam can be written (Esveld 2001)

$$
E I \frac{d^{4} \delta(x)}{d x^{4}}+k \delta(x)=0
$$

In the preceding, $E=$ Young's modulus of the rail $\left(\mathrm{N} / \mathrm{m}^{2}\right) ; I=$ moment of inertia of the rail $\left(\mathrm{m}^{4}\right) ; \delta(x)=$ vertical displacement at distance $x(\mathrm{~m})$; and $k=$ static track modulus $(\mathrm{N} / \mathrm{m} / \mathrm{m})$. The static track modulus $k$ was defined as the supporting force per unit length of rail, and $q(\mathrm{~N} / \mathrm{m})$ was the per unit displacement $\delta(\mathrm{m})$. For a track loaded by a discrete static wheel load $P_{s}(\mathrm{~N})$, the boundary conditions are $\delta(\infty)=0, \delta^{\prime}(0)=0$ and $\delta^{\prime \prime}(0)=P_{s} /(2 E I)$. By replacing the static wheel load $\left(P_{s}\right)$ with the dynamic wheel load $\left(P_{d}\right)$ obtained from Eq. (6), the solution of Eq. (7) is

$$
\delta(x)=\frac{P_{d}}{2 k L_{c}} e^{-x / L}\left(\cos \frac{x}{L_{c}}+\sin \frac{x}{L_{c}}\right)
$$

in which $L_{c}=$ characteristics length $(\mathrm{m})$ expressed as $(4 E I / k)^{1 / 4}$. The maximum displacement $\left(\delta_{\max }\right)$ is now given by

$$
\delta_{\max }=\frac{P_{d}}{2 k L_{c}}
$$


By using the principle of superposition, and Eqs. (8) and (9), displacement under the leading wheel load $\left(P_{d}\right)$ due to the effects of cumulative loading of the leading wheel and the subsequent wheels of the train is then given by

$$
\delta_{0}=\frac{P_{d}}{2 k L_{c}}\left[1+\sum_{i=1}^{n} r_{i} e^{-x_{i} / L_{c}}\left(\cos \frac{x}{L_{c}}+\sin \frac{x}{L_{c}}\right)\right]
$$

in which $x_{i}$ is the distance from the $i$ th wheel load $P_{d i}$ and $r_{i}=P_{d i} / P_{d}$. The dynamic track modulus $\left(k_{d}\right)$ was then obtained by measuring $\delta_{0}$ under the first wheel load and solving Eq. (10) iteratively for $k_{d}$. Data was collected from the aforementioned instruments at a frequency of $2,000 \mathrm{~Hz}$. The $E$ and $I$ for the rail were $210 \times 10^{9} \mathrm{~N} / \mathrm{m}^{2}$ and $30.55 \times 10^{-6} \mathrm{~m}^{4}$, respectively. Fig. 12(b) shows that the calculated track modulus varied significantly from one section to another and also illustrates the role of subgrade type and favorable effects of geogrids. Unlike the conventional approach, the dynamic amplification of a static wheel load was considered in this analysis. The track modulus for the fast train was about 40-60\% less than for the slow trains, which was much larger than that obtained by Esveld (2001) and Yang et al. (2009) on the basis of the dynamic magnification effect alone. The track modulus also decreased by about 20-40\% when the axle load increased from 25 to $30 \mathrm{t}$. Thus, the track modulus was influenced to a great extent by variations in the axle load, type of subgrade, and train speed. This deterministic approach is simple and illustrates how the train (axle load, speed), track substructure, and artificial inclusions affect the track modulus.

\section{Ballast Breakage and Fouling}

Samples of ballast were obtained from discrete locations along the track to evaluate the amount of particle breakage under repetitive wheel loads. They were collected during the intermittent periods of track shutdown $(130,307$, and 1,272 days after the track was commissioned). A $1.8 \times 1.3 \mathrm{~m}$ sampling pit was formed by excavating the ballast from the crib, shoulder, and load-bearing segments of the rail track. Samples were recovered from three equal portions between the bottom of the sleeper and the formation level, and were obtained in accordance with AS 1141.3.1 (AS 2012). Care was taken to collect fine particles trapped inside the voids of ballast. The ballast profile was then reinstated using clean ballast that was tamped by a tamping head on the excavator. Small containers were used to avoid segregation during the transport to the laboratory. A visual inspection of the samples revealed that fines mainly resulted from breakdown and attrition of ballast aggregates; there was no indication of external fouling due to coal or clay.

The extent of particle breakage was analyzed using the ballast breakage index (BBI) explained previously by Indraratna et al. (2005). The graphical method of determining the BBI is shown in Fig. 13(a), and the average BBI values are reported in Fig. 13(b). These results showed that ballast degradation increased with the number of cycles. The BBI values increased as the number of load cycles increased, which was consistent with laboratory measurements reported elsewhere (Sun et al. 2015). The BBI values for ballast layers reinforced with GG-3 were about $35 \%$ smaller than those without reinforcement, which verified that the geogrid reinforcement contributed to reduced ballast degradation. Although the typical train speeds of all experimental sections were almost the same, the effects of shockmats resulted most likely in a significantly smaller value of $\mathrm{BBI}(\mathrm{BBI}<5 \%)$. The interaction of the subgrade of high dynamic impedance [i.e., rigid foundations (bridge deck or rock foundation)] and the ballast aggregates and the frictional resistance of the ballast induces nonuniform axial and

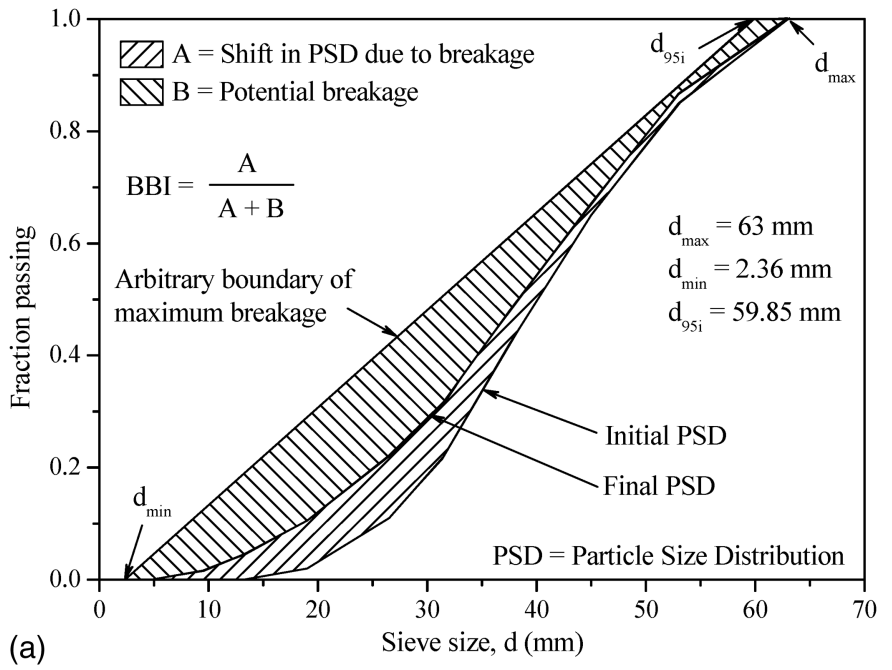

Number of load cycles, $\mathrm{N}\left(\times 10^{7}\right)$

$\begin{array}{llllllllllllllll}0.0 & 0.2 & 0.3 & 0.5 & 0.6 & 0.8 & 0.9 & 1.1 & 1.2 & 1.4 & 1.5 & 1.7 & 1.9 & 2.0 & 2.2 & 2.3\end{array}$

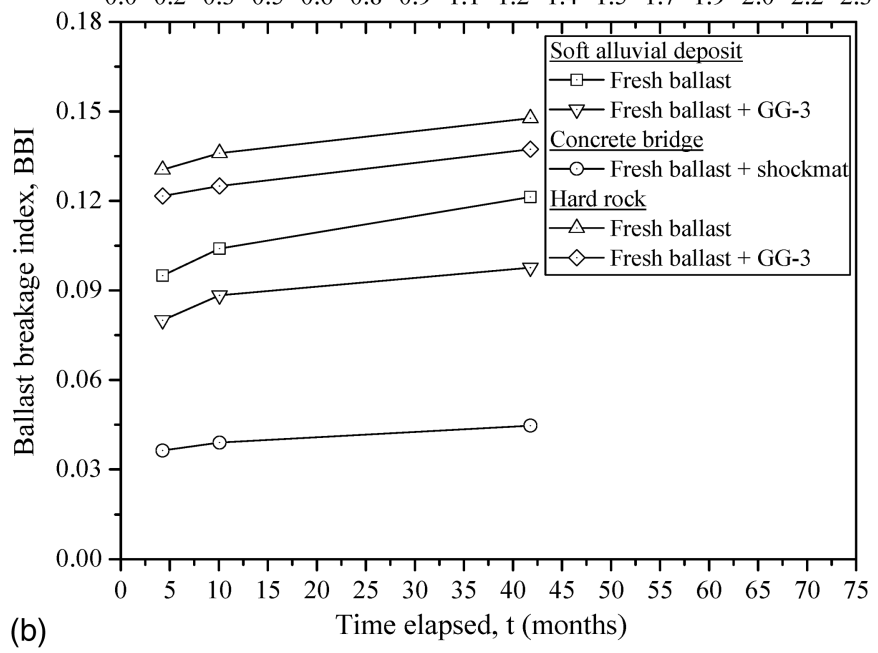

Fig. 13. (a) Determination of ballast breakage index (data from Indraratna et al. 2005); (b) its variation against different subgrade conditions

tangential end (boundary) stresses to develop at the ballastsubgrade interface. This phenomenon primarily contributes to the ballast breakage, and the use of shockmats could reduce the breakage significantly (i.e., in the order of 40-50\%) (Nimbalkar et al. 2012). Particle degradation was more pronounced for the stiff subgrade than for the relatively soft or weak subgrade. This result is consistent, because in practice, those sleepers on the approach between soft and stiff subgrade undergo the largest settlement $(\mathrm{Li}$ and Davis 2005) as well as increased track acceleration (Tutumluer et al. 2012), thus implying exacerbated ballast breakage.

\section{Conclusions}

Full-scale field monitoring was undertaken on sections of instrumented track to study how effectively various types of geosynthetics and shockmats would improve the overall performance of ballasted rail tracks. Five types of geosynthetics with different geometrical and mechanical properties were installed in experimental track sections constructed on three different subgrades. The track was then monitored for about 5 years, or $1.7 \times 10^{7}$ equivalent load cycles. 
The geogrids and geocomposites decreased the settlement of the ballast by almost $35 \%$, a result that would have significant implications on track maintenance. This percentage reduction in vertical deformation was greater on softer subgrades. Permanent strains up to $2.2 \%$ that developed in the reinforcing geogrids were generally larger and increased more rapidly in the transverse direction, where the track confinement was less. The characteristic deformation of the underlying track formation and subgrade also had a significant effect on the magnitude of cumulative strains (up to $1.3-2.0 \%$ ) of the reinforcing geogrids.

Traffic-induced vertical stresses at the sleeper-ballast interface were larger on stiffer subgrades. The geogrids reduced the transient track deformation by $40-65 \%$ at the soft alluvial deposit, and by $15 \%$ at the hard rock, a favorable practical result that would have significant implications on ride quality and safety at increased speeds. With the biaxial geogrids and geocomposites used in this study, the aperture sizes which resulted in the least amount of ballast deformation were in the range of $1.1 d_{50}$.

Significantly enhanced train speeds will always increase the dynamic forces and impart greater stresses onto the ballast. At the soft alluvial deposit, as train speed increased from 40 to $80 \mathrm{~km} / \mathrm{h}$, stresses at the sleeper-ballast interface increased by almost $10 \%$, and this amplification effect was more pronounced for the very stiff subgrade (hard rock). The track modulus varied significantly from one section to another, thus illustrating the role of subgrade type and the favorable influence of geogrids. The reduction in ballast breakage at the concrete bridge deck (stiff subgrade) to levels less than $5 \%$ could be attributed to the use of a shockmat. The findings of this full-scale field study have enabled a better assessment of how synthetic inclusions would improve the overall track performance under repetitive wheel loads. In ballasted tracks, stresses and dynamic amplification effects were more pronounced than ballastless tracks. Ballast particles undergo a higher degree of breakage resulting from more intensive dynamic loading. A better understanding of such performance would allow for more effective design and analysis of ballasted tracks reinforced with geosynthetic inclusions and improved by rubber shockmats.

\section{Acknowledgments}

This study was financially supported by the Cooperative Research Centre for Rail Innovation and Australian Research Council Centre for Excellence in Geotechnical Sciences and Engineering. This financial support is gratefully acknowledged. The authors wish to thank Tim Neville (ARTC), David Christie, Sandy Pfeiffer, and Jatinder Singh of Sydney Trains (formerly, RailCorp Sydney) for their comments and suggestions. The on-site assistance provided by Carol Bolam, Tony Miller, and Darren Mosman of Hunt8r Alliance (Newcastle) and David Williams of ARTC (Newcastle) is appreciated. The authors would also like to thank Alan Grant, Cameron Neilson, and Ian Bridge of the University of Wollongong for their technical support throughout the period of this study.

\section{References}

Allen, T. M., and Bathurst, R. J. (1996). "Combined allowable strength reduction factor for geosynthetic creep and installation damage." Geosynth. Int., 3(3), 407-439.

Anderson, J. S., and Rose, J. G. (2008). "In situ test measurement techniques within railway track structures." Proc., ASME/IEEE/ASCE Joint Rail Conf., ASME Rail Transportation Division, New York.

AS (Australian Standard). (1996). "Aggregates and rock for engineering purposes." AS 2758.7, Sydney, NSW, Australia.
AS (Australian Standard). (2012). "Methods for sampling and testing aggregates method. 3.1: Sampling-aggregates." AS 1141.3.1, Sydney, NSW, Australia.

Ashmawy, A. K., and Bourdeau, P. L. (1995). "Geosynthetic-reinforced soils under repeated loading: A review and comparative design study." Geosynth. Int., 2(4), 643-678.

ASTM. (2001). "Standard test method for determining tensile properties of geogrids by the single or multi-rib tensile method." ASTM D6637-01, West Conshohocken, PA.

Audley, M., and Andrews, J. D. (2013). "The effects of tamping on railway track geometry degradation." Proc. Inst. Mech. Eng. Part F: J. Rail Rapid Transit, 227(4), 376-391.

Aursudkij, B., McDowell, G. R., and Collop, A. C. (2009). "Cyclic loading of railway ballast under triaxial conditions and in a railway test facility." Granular Matter, 11(6), 391-401.

Bathurst, R. J., Allen, T. M., and Walters, D. L. (2002). "Short-term strain and deformation behavior of geosynthetic walls at working stress conditions." Geosynth. Int., 9(5-6), 451-482.

Bian, X., Jiang, H., Cheng, C., Chen, Y., Chen, R., and Jiang, J. (2014). "Full-scale model testing on a ballastless high-speed railway under simulated train moving loads." Soil Dyn. Earthquake Eng., 66(11), 368-384.

Clayton, C. R. I., and Bica, A. V. S. (1993). "The design of diaphragm-type boundary total stress cells." Géotechnique, 43(4), 523-535.

Costa, P. A., Calçada, R., and Cardoso, A. S. (2012). "Ballast mats for the reduction of railway traffic vibrations. Numerical study." Soil Dyn. Earthquake Eng., 42, 137-150.

Delaney, M. (2011). Geotechnical investigation of specific areas of track formation concern for Minimbah bank stage 1 third track, Newcastle Geotech, NSW, Australia.

Dunnicliff, J. (1988). Geotechnical instrumentation for monitoring field performance, Wiley, New York.

Ebersöhn, W., and Selig, E. T. (1994). "Track modulus measurements on a heavy haul line.” Transp. Res. Rec., 1470, 73-83.

Esveld, C. (2001). Modern railway track, MRT Productions, Zaltbommel, Netherlands.

Fernandes, G., Palmeira, E. M., and Gomes, R. C. (2008). "Performance of geosynthetic-reinforced alternative subballast material in a railway track." Geosynth. Int., 15(5), 311-321.

Ferreira, P. A., and López-Pita, A. (2013). "Numerical modeling of high-speed train/track system to assess track vibrations and settlement prediction." J. Transp. Eng., 10.1061/(ASCE)TE.1943-5436.0000482, 330-337.

Göbel, C. H., Weisemann, U. C., and Kirschner, R. A. (1994). "Effectiveness of a reinforced geogrid in a railway subbase under dynamic loads." Geotext. Geomembr., 13(2), 91-99.

Indraratna, B., Biabani, M. M., and Nimbalkar, S. (2015). "Behaviour of geocell reinforced subballast subjected to cyclic loading in plane strain condition." J. Geotech. Geoenviron. Eng., 10.1061/(ASCE)GT.1943 -5606.0001199, 04014081-1-04014081-16.

Indraratna, B., Lackenby, J., and Christie, D. (2005). "Effect of confining pressure on the degradation of ballast under cyclic loading." Geotechnique, 55(4), 325-328.

Indraratna, B., and Nimbalkar, S. (2013). "Stress-strain degradation response of railway ballast stabilized with geosynthetics." J. Geotech. Geoenviron. Eng., 10.1061/(ASCE)GT.1943-5606.0000758, 684-700.

Indraratna, B., Nimbalkar, S., Christie, D., Rujikiatkamjorn, C., and Vinod, J. S. (2010). "Field assessment of the performance of a ballasted rail track with and without geosynthetics." J. Geotech. Geoenviron. Eng., 10.1061/(ASCE)GT.1943-5606.0000312, 907-917.

Indraratna, B., Nimbalkar, S., and Neville, T. (2014a). "Performance assessment of reinforced ballasted rail track." Ground Improv., 167(1), 24-34.

Indraratna, B., Nimbalkar, S., and Rujikiatkamjorn, C. (2014b). "From theory to practice in track geomechanics-Australian perspective for synthetic inclusions." Transp. Geotech., 1(4), 171-187.

Indraratna, B., and Salim, W. (2003). "Deformation and degradation mechanics of recycled ballast stabilised with geosynthetics." Soils Found., 43(4), 35-46. 
Indraratna, B., Shahin, M. A., and Salim, W. (2007). "Stabilising granular media and formation soil using geosynthetics with special reference to railway engineering." Ground Improv., 11(1), 27-43.

Indraratna, B., Tennakoon, N., Nimbalkar, S., and Rujikiatkamjorn, C. (2013). "Behaviour of clay fouled ballast under drained triaxial testing." Géotechnique, 63(5), 410-419.

Jeffs, T., and Tew, G. P. (1991). A review of track design procedures: Sleepers and ballast, Railways of Australia, Australia.

Jenkins, H. H., Stephenson, J. E., Clayton, G. A., Morland, G. W., and Lyon, D. (1974). "The effect of track and vehicle parameters on wheel/rail vertical dynamic forces." Railway Eng. J., 3(1), 2-16.

Kennedy, J. H., Woodward, P. K., Banimahd, M., Medero, G. M. (2012). "Railway track performance study using a new testing facility." Proc. ICE - Geotech. Eng., 165(5), 309-319.

Krylov, V. V. (2001). Noise and vibration from high-speed trains, Thomas Telford, London.

Li, D., and Davis, D. (2005). "Transition of railroad bridge approaches." J. Geotech. Geoenviron. Eng., 10.1061/(ASCE)1090-0241(2005)131: 11(1392), 1392-1398.

Li, D., and Selig, E. T. (1998). "Method for railroad track foundation design. II: Applications." J. Geotech. Geoenviron. Eng., 10.1061/(ASCE) 1090-0241(1998)124:4(323), 323-329.

Luo, Y., Yin, H., and Hua, C. (1996). "Dynamic response of railway ballast to the action of trains moving at different speeds." Proc. Inst. Mech. Eng. Part F: J. Rail Rapid Transit, 210(2), 95-101.

MATLAB 7.9.1 [Computer software]. MathWorks, Natick, MA.

Neidhart, T. (2001). "True-to-scale in situ tests determining dynamic performance of earthworks under high speed train loading." Proc., Geotechnics for Roads, Rail Tracks and Earth Structures, ISSMGE, Rotterdam, Netherlands, 213-223.

Nimbalkar, S., Indraratna, B., Dash, S. K., and Christie, D. (2012). "Improved performance of railway ballast under impact loads using shock mats." J. Geotech. Geoenviron. Eng., 10.1061/(ASCE)GT.1943 $-5606.0000598,281-294$.

Priest, J. A., and Powrie, W. (2009). "Determination of dynamic track modulus from measurement of track velocity during train passage." J. Geotech. Geoenviron. Eng., 10.1061/(ASCE)GT.1943-5606.0000130, $1732-1740$.
Raymond, G. P. (2002). "Reinforced ballast behaviour subjected to repeated load." Geotext. Geomembr., 20(1), 39-61.

Raymond, G. P., and Bathurst, R. J. (1994). "Repeated-load response of aggregates in relation to track quality index." Can. Geotech. J., 31(4), $547-554$

RCA. (2008). Geotechnical investigation report for Minimbah bank third track, Newcastle, NSW, Australia.

Rose, J., Su, B., and Twehues, F. (2004). "Comparisons of railroad track and substructure computer model predictive stress values and in situ stress measurements." Proc., Annual Conf. and Exposition, American Railway Engineering and Maintenance-of-Way Association, Lanham, MD.

Selig, E. T., and Waters, J. M. (1994). Track geotechnology and substructure management, Thomas Telford, London.

Suiker, A. S. J., Selig, E. T., and Frenkel, R. (2005). "Static and cyclic triaxial testing of ballast and subballast." J. Geotech. Geoenviron. Eng., 10.1061/(ASCE)1090-0241(2005)131:6(771), 771-782.

Sun, Q. D., Indraratna, B., and Nimbalkar, S. (2014). "Effect of cyclic loading frequency on the permanent deformation and degradation of railway ballast." Géotechnique 64(9), 746-751.

Sun, Q. D., Indraratna, B., and Nimbalkar, S. (2015). "Deformation and degradation mechanisms of railway ballast under high frequency cyclic loading." J. Geotech. Geoenviron. Eng., 10.1061/(ASCE)GT.1943 $-5606.0001375,1-12$.

Sussmann, T. R., Ebersöhn, W., and Selig, E. T. (2001). "Fundamental nonlinear track load-deflection behavior for condition evaluation." Transp. Res. Rec., 1742, 61-67.

Talesnick, M. (2005). "Measuring soil contact pressure on a solid boundary and quantifying soil arching." Geotech. Test. J., 28(2), 171-179.

Tutumluer, E., Stark, T. D., Mishra, D., and Hyslip, H. S. (2012). "Investigation and mitigation of differential movement at railway transitions for US high speed passenger rail and joint passenger/freight corridors." Proc., Joint Rail Conf., ASME, New York, 75-84.

Weiler, W. A., and Kulhawy, F. H. (1982). "Factors affecting stress cell measurements in soil." J. Geotech. Eng. Div., 108(GT12), 1529-1548.

Yang, L. A., Powrie, W., and Priest, J. A. (2009). "Dynamic stress analysis of a ballasted railway track bed during train passage." J. Geotech. Geoenviron. Eng., 10.1061/(ASCE)GT.1943-5606.0000032, 680-689. 